\title{
IMPACT OF UTILITY WORKS IN ROAD PROJECTS IN SRI LANKA AND PROPOSED MITIGATION MEASURERS
}

\author{
MOHAMED ISMAIL.J ${ }^{1}$, DE SILVA. M. L ${ }^{2}$ \& WAIDYASEKERA, K.G.A.S. ${ }^{3}$ \\ 1,2,3 University of Moratuwa, Katubedde, Sri Lanka \\ 1jmismail87@gmail.com, 2habitat.archi@gmail.com, 3anuradha@uom.com
}

\begin{abstract}
Road projects are experiencing huge delays in Sri Lanka due to utility relocation, delays in releasing payments, design changes during construction phase, price escalation and land acquisition to accommodate utility relocation. In some instances, contract of utility projects was awarded when road works were nearing completion. There is no sound legislation that exists defining the powers, rights and obligations of Roads and Utility authorities. As a result, Roads Authorities in Sri Lanka are obliged to pay all costs associated with the above impacts, along with extension of time due to such delays from the allocated funds for road works. This has been causing burden to the project scope and impacting the economy of Sri Lanka. As such, it is important to identify suitable remedial measures to mitigate such impacts during the design and construction stages. Qualitative research method was adopted through the inductive process by selecting purposive samples of experts for semi structured in-depth interviews. In addition, more data was collected through documents review. This study revealed that the knowledge gap in the sector to identify and recommended remedial measures for impacts caused by utility works in road projects in Sri Lanka.
\end{abstract}

Keywords: mitigation measures, relocation; roads; Sri Lanka; utility works.

\section{Introduction}

Utilities (water, electricity, and gas) are generally defined as essential amenities that are important to the economy and development of society (International Labour Organisation, 2019). Utilities such as electricity, gas, water, or sewerage have been supplied by an organization to the community.. Utilities, including services, are usually referred to as basic facilities. Infrastructure developments are essential for a community to work, such as road network, potable water, electricity, communications facilities, and public necessities etc. The problem with these types of projects are that they are often miscalculated, either in terms of their financial plan and/or the time.

As per the research findings of Wijekoon and Attanayake (2010), the second highest reason for delays in the completion of road projects in Sri Lanka were due to relocation or shifting of utilities. The construction work of the Colombo Baseline project (1) was delayed by 22 months, out of which the delay of 19 months was due to the relocation of utilities. This included water transmission and telecom lines (Teruo, 2005). The project cost for Phase 1 of the Base Line Road reached up to LKR 3,645 million, a substantial increase over the estimated cost of LKR 2,662 million. This was due to the expenses incurred in the relocation of utilities, and the amount for consultancy and civil works were also increased due to the delay in the execution of the project (Teruo, 2005).

The growing number of infrastructural development projects being planned, executed, and implemented in Sri Lanka have given rise to many issues infringing the economic and budgetary challenges during project management (Pathiranage and Halwathura, 2010). Due to governmental or political pressure, roads and infrastructure projects were tendered and awarded for construction without adequate planning, investigation of subsurface soil conditions and existing underground utilities (Ismail,2020). This 
often results in dealing with the 'unexpected' as in most cases, there are no cost and time provision in the contracts. Therefore, as a result, organisations will maintain the status quo of existing underground utilities by providing protection or to relocate utilities and/or carryout betterment works (increase in capacity and /or size). This causes extensive delays and cost implication in the project implementation.

As seen from the foregoing, there are serious unresolved issues and challenges relating to utility works projects which do exist to a great extent in Sri Lanka. These issues may arise with contractors, which puts additional pressure on not only the implementers but also end-users, the people whose rights have been infringed. It is therefore very important to identify the impacts of utility works during the planning and design stage. The procedure of the utility relocation/ betterment works should be focused on in an indepth study to investigate and to reveal the reality behind them. However, without a proper in-depth study and analysis, the system cannot be addressed for the required improvement. Therefore, it is necessary to investigate the extent of the knowledge gap in the subject to identify the areas to develop the sector by analysing the procedures. This paper presents mitigation measures for impacts caused by utility works in road projects in Sri Lanka.

\section{Literature Synthesis}

The literature review of utility diversion and betterment works in roads projects and their impact have revealed the following information. Roads authorities in Sri Lanka are obliged to pay all costs associated with relocation and betterment works. As a result, approximately 30-35\% portion from the allocated funds for road works are transferred towards unforeseen utility related works.

\subsection{IMPACT OF UTILITY WORKS IN ROAD PROJECT WORKS}

The main reason behind the result of utility diversion is due to the fact that underground utilities have not been properly investigated and included in the design drawings and scope of work. They were only discovered during the construction stage. As a result, much time has been spent trying to coordinate with various utilities, such as water supply, sewerage, telecom, and electricity supply, which had administrative authority over these services (Teruo,2005). Delays in to road construction projects are inevitable since majority of these projects commence works before relocation of utilities. Therefore, it is very important that the scope of utility relocation is to be identified during design stage and the relocation process to be initiated to avoid any delays to construction activities (Wijekoon and Attanayake, 2010). Pathiranage and Halwatura (2010) found in their study that the road construction projects in Sri Lanka exceeded the initial (planned) project period by $56-88 \%$ of the average overrun time. Although subsoil ground conditions seldom can be carefully assessed, comprehensive planning and investigations are required before construction begins (about underground utilities) to reduce the impact of any unforeseen discoveries (Pathiranage and Halwatura,2010). According to another study by Jayakanthan and Jayawardene (2012), delays caused by utility diversion in donor funded projects stood at the 11 th most influencing factor among 30 identified factors causing delays.

Key factors affecting the effect of utility works include the complexity of projects, lack of information on underground utilities, lack of experience of contractors on certain types of special projects and lack of knowledge of local regulations (Roachanakanan, 2005). Consequently, approximately $30-35 \%$ of the portion from the allocated funds for road works were transferred towards unforeseen utility related works. Moreover, there is no sound legislation that exists defining the powers, rights and obligations of roads and utility authorities and service providers (Ismail,2020). Utility Service providers usually insist on using their own consultants and approved contractors to carry out the work on their infrastructure. At times, the rates charged by the utility provider's contractor were significantly higher than those secured by the roads authorities (Department of Transport Abu Dhabi, 2013). The process of land acquisition and relocation took nearly seven years in a Road Network Improvement Project (RNIP), two years longer than expected, resulting about $40 \%$ of the project delay (Jayakanthan and Jayawardene, 2012).

Many road projects in Sri Lanka are facing greater delays, which in many ways adversely affect the progress of the nation and economy resulting in socio-economic problems and therefore an urgent mitigation is needed (Pathiranage and Halwathura, 2010). As such, there needs to be changes that should be imposed in communication and co-ordination with utility authorities. This is due to delay in project site hand over, approvals of drawings, method statement approval and shutdown. These critical issues have caused significant contractual problems to road contractors. This leads to high risks resulting from unexpected site ground conditions and several challenges and difficulties in locating underground utilities 
(Perera, Dhanasinghe and Rameezdeen,2009). Therefore, during this period effective coordination with the utility authorities' project team is very crucial to undertake the shifting of utilities without leaving the relocation in the future during the construction period (Jayakanthan \& Jayawardene, 2012).

\subsection{EFFECTIVE WAYS OF DEALING WITH UTILITY WORKS DURING ROAD PROJECT WORKS IN DEVELOPED COUNTRIES}

The second aspect of the literature synthesis is to explore effective ways of dealing with utility authorities in developed countries during road project works. Developed countries such as the US, Canada, European Nations, Australia, and New Zealand have established states or provincial level laws and regulations to regulate the placement of most utilities on road reserves (Ismail,2020).

While the legislation may differ between states in these countries, they are based on the similar principles that the agency responsible for the need to relocate utility infrastructure is also responsible for the relocation costs but not for betterment work (Victoria State Government, 2004). Utilities normally pay $100 \%$ of relocation costs in the United States, when utilities are found in right-of-way and are forced to divert to facilitate road project works. (US Transportation Department-Federal Highway Administration, 2014). In Ontario, Canada, the Act on Highways for Public Service Works allows for the road and utility authorities to mutually decide on cost allocations. For situations where no compromise exists, the expenses are shared equally. However, the disputing parties can appeal to the Ontario Municipal Board for a decision on fair cost sharing (Transport Association of Canada, 2016). In Europe most of the utilities are owned by private parties, although they serve the public, and are usually allowed to use public rights of way. When their services need to be moved to accommodate highway construction, they would typically be expected to do so at their own cost. England and Germany are just two noted exceptions, in England, utilities pay $18 \%$ of the diversion cost and the roads authority pays $82 \%$ of the rest. In Germany, the German highway authority is obliged to pay for the diversion when a company owns the property interest at its current location (Federal Highway Administration, 2014).

According to Asphalt Industry Alliance (2018) utility companies for road openings are spending each year an average of $£ 1.3 \mathrm{~m} \mathrm{(11 \% )}$ of their carriageway maintenance budget. Excavating a carriageway to create a trench can decrease its structural life by up to $30 \%$. The utility openings are of a higher number in England and Wales, which can have a damaging consequence (Asphalt Industry Alliance, 2018). When the road and utility authorities fail to agree on diversion costs, the dispute is likely to delay work. Consequently, the road authority will provide funds as an advance for construction costs to the utility authority under an agreement called pre-financing. Once the cost sharing compensation is settled or determined by a court, the utility authority returns any overpayment to the road's authority (Federal Highway Administration, 2014).

Australian states usually compensate utility authorities for the diversion of assets owned by the utility agencies (but not for betterments). Historically, majority of the utility authorities and operators have been government bodies. Therefore, whoever was obligated to pay for relocation work was of the opinion the funding came from the same source, where this attitude affects the project schedule and cost. However, the policy remains unchanged that the authority responsible for the road project requires the need for the diversion is also responsible for the utility diversion costs. In recent past, the Australian utility organizations industry have amended the regulation, with a higher percentage of utility agencies are now in private hands. However, the policy for reimbursing utility diversion continues as before (Victoria State Government, 2004). In Queensland, the Department of Transport and Main Roads (TMR) has two MOUs in place, one with the major electric utility (Energex) and the telecommunication utility (Telstra). One of the issues addressed in the MOU's is seeking to provide corridors which take into consideration future road planning to minimize the need for future relocation (Department of Transport Report on International Benchmarking Tour, 2013).

Cost sharing arrangements in New Zealand are normally resulted from negotiation between the affected parties as per legislation. On State Highways, for instance, gas, electricity, and telecommunications utilities are governed by the Gas Act (11), the Electricity Act (12) and the Telecommunications Act respectively (13) within a state where the utilities are located on highways. The general law is that the New Zealand Transport Agency (NZTA) will pay for the cost of relocation of the utilities with the exception that the charges for all fittings shall be borne by the utility owner (New Zealand Ministry of Transport, 1989). If the utility owner wants the work done in accordance with specifications different from those of the original works, the utility owner pays the difference between what it would have costed to relocate 
and reconstruct the works to their original specifications and the actual cost of the relocation and reconstruction (New Zealand Ministry of Transport, 1989).

In Australia, an Infrastructure Advisory Committee to advise the Victorian government on matters related to the occupation and use by utilities of the right of way was established as per the provision of the Road Management Act 2004. The members from Vic Roads, Utility authorities, local governments and public transport represented and provided their inputs to the Advisory Committee on Infrastructure and services. The panel members of the Advisory Committee provided advice in a number of areas, including governance, applicability of code of practice, coordination of utilities works and other occupants and road users of the right of way. Moreover, utility authorities and other stake holders made use of the panel as a consultation body regarding the use of the right of way (Victoria State Government, 2004). Similar committees have been established such as "Road Share", "Street Opening Conference "and "Service Coordination Committee" in the U.S, New Zealand and UAE respectively (Department of Transport Abu Dhabi, 2013).

\subsection{METHODS OF CO-OPERATION, CO-ORDINATION, COLLABORATION AND COMMUNICATION OF UTILITY WORKS IN ROAD PROJECTS}

Generally, all countries included in the literature survey embrace good practices and initiatives for relocation of utilities falling within rights of way. These are supported by legislation and/or agreements between the road's authorities and the utility service providers. It was also noted that utility work management is rarely considered in isolation but, rather forms part of the wider concept of utility relocation and accommodation. This includes promoting cooperation, coordination, and communication, provision of utility corridors, avoiding unnecessary utility relocations, cost sharing of the works for relocation and betterment works and establishing utility agreements. Jayakanthan and Jayawardene (2012) found out through their research in Sri Lanka for donor funded projects issues such as insufficient stakeholder participation, poor or unsuccessful communication with stakeholders throughout the project, failure to recognize all stakeholders and their demands. There were many issues that led to disputes and misunderstandings during the execution phase of the project.

Right of Way (ROW) owners in Canada are responsible for the construction and management of infrastructure within ROWs, and act in the best interests of all stakeholders. It is both, the ROW regulatory authorities and utility service providers' responsibility to design consistent, competent, and well-organized coordination process for utilities (Transportation Association of Canada, 2016). The findings of a 2008 study conducted by the Canadian Transportation Association have stated in a report entitled "The Management of Utilities in and adjacent to Public Right-of-Way: Survey of Practices", (while the method of organizing work with utility companies differs across jurisdictions), the report suggests that there is broad agreement on the issues of utilities facing road authorities, including, disruption and increase in costs to road projects are caused by the following utility diversions:

- Utilities "as built drawings" data and site location detail of existing underground assets which are often found inaccurate and poor in quality,

- When utility service providers excavate or cut newly laid road carriageways, there are additional burden of cost incurred by road authorities as a consequence of a reduction in road service life,

- To ensure reasonable costs share of all utility related works within the right-of-way, there is significant effort which is needed from all concerned stake holders.

In 1998, a Federal Highway Administration (FHWA) research found that the lack of co-operation, communication and coordination to be the most important utility-related challenges and problems. While some roads and transport state authorities are maintaining very good working relationships with utility companies and utility coordinating committees, who are active between selected roads and utility authorities. However, this is not practiced in all states. In the Netherlands, the highway agency has established a good working relationship with utility companies by stressing continuous communication, cooperation and emphasis on team work to execute projects between highway and utility team members, as well as within their respective authorities and department (Federal Highway Administration, 2014). The Utilities Division of the Montana Department of Transportation's (MDT) Right-of-Way Bureau works in conjunction with utility companies to identify relocation alignments, create cost-sharing agreements and provides guidance on issues and works directly with utility companies (U.S. Department of TransportationFederal Highway Administration, 2014). Generally speaking, Australia's road authorities require service authorities to position their assets in the road reserve. Unless they adhere to their accepted agreement and 
have the permit that allowed them to be there, then any costs of relocation are the responsibility of the troubling party. There have been cases where the utility service providers have failed to comply, in which case the road authority has kept the service provider responsible for the costs of relocation or even incurred the costs of penalties to the utilities. (Government of the Victoria State, 2004).

\section{Research Method}

The first step of the research process was conducted through a wide-ranging literature survey covering the aspects of impacts of utility works in road project works. In addition, current practices available in roads and transportation authorities of developed countries was explored particularly relating to utility works in road projects. Mainly, evidence from literature was used by referring to journal articles, books, conference proceedings, industry reports and documents from sources from both overseas and Sri Lanka.

Secondly, qualitative research method adopted through inductive process by selecting purposive samples of experts for semi structured in-depth interviews with key team leaders, specialists of roads and utility authorities and other applicable government entities in Sri Lanka and overseas to identify their expertise in execution, views and advice in roads, infrastructure, rail and utility projects. In drawing the requisite conclusions for qualitative approach the expertise of the relevant government, semi government, private institution officials were scrutinised in detail for the appropriate policy and legal framework. Twelve focused interviews were conducted with senior advisors, project directors, general managers, senior project managers, legal experts, and team leaders representing roads, utilities, transportation, and light rail authorities. The interviewed participants were highly experienced practitioners representing those fields, enriched by new information, in line with their respective fields, current practices and procedures. They all have an average of over 25 years of experience with their professional fields respectively. Details of respondents are given in Table 1.

The qualitative data collected from multiple sources were analysed by adopting the deductive approach based on a semi -structured predetermined questions. After transcribing, transforming and arranging, the collected data were organized and arranged in an orderly manner based on research objectives. Thereafter, proper codes for the collected data were arranged to compress large amount of information collected. The coding of qualitative data simply means categorizing and assigning properties and patterns to the collected data and findings were summarized and recommended options and viable solutions were identified.

\begin{tabular}{|l|l|l|l|}
\hline Respondent & Profession/Designation & Industry Experience & $\begin{array}{l}\text { Level of Awareness } \\
\text { / Experience } \\
\text { in Practice }\end{array}$ \\
\hline REI & Director-Design & 31 years & High \\
\hline RE2 & DGM-WPS2 & 33 years & High \\
\hline RE3 & Project Director & 28 years & High \\
\hline RE4 & DGM-NCP & 25 years & High \\
\hline RE5 & Director- Legal & 30 years & High \\
\hline RE6 & AGM- Development & 28 years & High \\
\hline RE7 & Project Manager & 08 years & Moderate \\
\hline RE8 & Senior Advisor-Major Projects & 30 years & High \\
\hline RE9 & Director-Engineering & 35 years & High \\
\hline RE10 & Chief Engineer & 15 Years & High \\
\hline RE11 & DGM /Project Director & 35 Years & High \\
\hline RE12 & Project Engineer & 08 Years & Moderate \\
\hline
\end{tabular}

Table 1: Details of Respondents

\section{Research Findings}

Research findings were accomplished through literature survey, document review and data collected from semi structured expert interviews. Literature findings revealed that road projects in Sri Lanka suffered numerous impacts as a result of both in dealing with utility authorities and in executing utility works in 
right of ways. On the other hand, literature survey highlighted several well established good practices and regulatory measures in dealing with utility authorities for successful completion of road projects in developed countries. However, in the Sri Lankan context, much need to be done to build up and strengthen this particular segment of the construction industry. More details discovered through semi structured expert interviews are discussed below.

\subsection{CURRENT PRACTICE OF UTILITY WORKS IN ROAD PROJECTS IN SRI LANKA \& ITS IMPACTS}

Majority of the respondents (RE2, RE3, RE6, RE9, RE10, RE11 and RE12) opined that on many occasions utility authorities were not in possession of their own "as-built drawings" with required accuracy in showing the correct location, line, and depth of their existing utilities. As a result, road contractors were compelled to carry out trial pits to locate existing locations of their services by spending additional amount and extra time.

Respondent (RE3) stated that generally permission granted to relocate electrical overhead poles between two shackle points as minimum length which is from 16 to 18 poles distance. Similarly, telecom authority too permitted to relocate fibre optic cable between chamber to chamber as minimum length. Therefore, no further construction work was possible in this section by the road contractors until the entire relocation was completed. This in turn attracted contractual cost and time implications. Respondents (RE3 and RE8) further added that sometime utility assets were shifted temporarily until such time road related works in that section was completed and relocated to its original location. It was also learnt from respondents (RE6, RE9 and RE 11) that in the case of water supply pipe relocation, long lengths and bends were avoided due to pressure drop. The other reason for this approach was due to the fact that pipe joints, "specials", fittings, couplers and concrete thrust blocks are expensive and are not freely available.

Another respondent (RE7), project manager of a road project, informed that in one road project, the electricity authority refused to grant shutdown for relocation during the month of August to avoid disruption of services for GCE A/L examination. On the other hand, telecom authority insisted their entire assets to be shifted between chamber to chamber. Respondent (RE7) added that utility authorities also insisted payment in advance to commence relocation of their assets, whereas the road contractor was unable to pay since road project contract agreement was not formalized. The above stringent requirements were not made known in advance not even as conditions of granting construction permit. There were hardly any coordination and communication during the entire process of construction relocation of utilities. Even after receiving payment utility authorities took about another month to visit the project site to arrange relocation. Respondent (RE3) further added that, utility authorities refuse to relocate their assets until substantial length of land acquisition is completed and compensated. This approach had caused considerable delays in issuing construction permits / No objection Certificate (NOC), shutdown for relocation works, approval of shop drawings etc. As a result, the project suffered almost $70 \%$ delay and several other contractual implications.

One of the respondent (RE8) pointed out "In most part of the world, the problem of cost overrun in the construction industry is very acute and severe. There is a need to study more to improve this serious situation. This is a common issue found generally in most of the projects and locations. Simply because we have not shared the lessons learnt when we complete a project, we don't sit and discuss what happened, what went wrong, what could be better? If it was better, what could be better than that? We don't ask these questions, we keep complaining and we keep changing people, blame culture which does not solve the problem." The respondent representing water authority (RE10) stated that there are four major hurdles which were causing impact on road projects such as non-availability of funds at the right time which attributes $70 \%$ of the impact, cost overrun, then absence as-built details (whatever available most of them are found to be inaccurate) and restricted working hours (only in the nights) in Colombo city. On the other hand, right of ways were congested with underground utilities adds up to remaining $30 \%$ of the impact and problems.

Respondent (RE6) added that in one of the water projects in Colombo district, LKR.1 million was allocated exclusively for road reinstatement works as provisional sum, but later road authority estimated the actual reinstatement cost as LKR. 98 million. In order to accommodate the additional funds needed for road reinstatement works, $14 \mathrm{~km}$ length of pipe line works from the original scope was reduced. In addition to this, pipe lines for future demand were also deleted. Opposite of this also true when dealing with utility relocation works, original scope of road works was reduced to compensate for utility relocation and at times for betterment works too. 
All the respondents emphasized that the site inspection by authorities were not done on regular basis. Further, respondents (RE3, RE6 and RE10) provided following additional information regarding impacts due to utility relocation and/or betterment works. Funds from donors such as ADB, World Bank, JICA, European Union, Saudi, Kuwaiti Fund were granted at different interval of time for infrastructure projects and not simultaneously. Major projects for roads, water, telecommunication, sewerage and electricity were financed under the above mentioned donor funds and were implemented at different periods due to lack of coordination and communication during planning, design and construction stages. There were occasions where, funds for major utility services projects were sanctioned when the road projects were just about to complete or shortly after completion, causing abortive works and wasteful expenditure of public funds. Deep excavation and utility trenches across and along the roads were causing perennial inconvenience to traffic and general public and eventually reduced the life span of newly completed roads. Utility authorities do not have a database of their assets and therefore service lines they show in their drawings are not to scale. On number of occasions quantities have increased to several folds, whereas what was indicated in the 'As built' drawing as one line but it could be 10 and even more. As stated by respondents (RE3, RE6, RE10, RE11 and RE12) accuracy of database is not more than $30 \%$ and $70 \%$ is left as a risk to road contractor and create ideal grounds for claims. Moreover, service outage experienced during utility works not only caused inconveniences to public, but also loss of revenue for both trading companies and service providers. In addition to all these hassles, as per the current practice project owners are responsible for payment of relocation charges and/or for betterment of utility works because there were no cost sharing agreements and lack of communication and coordination between concerned stake holders.

Respondents representing donor funded road projects (RE3, RE6, RE9 and RE11), stated that land acquisition process contributing substantial delay in utility relocation. Land acquisition proposal has to be initially submitted to Survey Department. Thereafter, application has to be submitted to Land Department through Divisional Secretariat of the affected area for gazette notification. Finally, Valuation Department need to finalize the compensation. The bureaucracy and time involved in the entire process consumed almost 2 years. In many projects it so happened that projects were awarded with minimum or no investigation whatsoever of existing underground utilities, whereas in some instances roads and utility relocation works were held up until such time land acquisition was finalized and suitable service corridor were identified and allocated. Multiple effects of this had caused the project completion for couple of years resulting in huge cost overrun. Respondent (RE5) added that there were instances projects ends up in arbitration too adding fuel to fire. If sufficient time equivalent to this delay period were spent early or during planning and design stages several hundreds of million rupees could have been saved.

\subsection{PROPOSED MITIGATION MEASURES TO REDUCE IMPACT OF UTILITY WORKS IN ROAD PROJECTS IN SRI LANKA}

Most of the respondents emphasized urgent need for and importance of establishing a new organization under the title of "National Utility \& Roads Coordination Entity (NURCE)" representing roads and utility authorities. Literature findings also revealed similar entities are in operation in the U.S, Australia, New Zealand and UAE (Department of Transport Abu Dhabi, 2013).

This entity will be of immense benefits to all stake holders in many ways in terms of sharing current, near and long-term master plans. It will also assist in solving issues of projects in planning, design and finally construction stages. The other aspect is to establish cost share agreements between all stake holders for relocation and betterment works across the board for an initial period of 3 years instead of the current ad-hoc agreements, MOUs for limited projects and resources sharing. It appeared from the response that word 'cost sharing' had different levels of understanding not merely in terms of utility relocation for betterment works as well. Moreover, as stated by respondents (RE1, RE3, RE4, RE6, RE9, RE10 and RE11) due to the construction industry's technical nature, no one took notice to educate enormous benefits and contemplated for it to be legislated.

Respondent (RE8) mentioned that as in the case of developed countries, a dedicated Utility Coordination Division or Right of Way division functioning as part of road authorities to exclusively coordinate and communicate with utility authorities should be established. This division should be also tasked in developing MOUs, SLAs, or any other overall agreement between authorities. Through these practices, projects can be completed on schedule, to the required quality, completed within budget and maintain proper procedures and process in place for dealing with utilities in all projects. Literature review revealed that all developed countries including Australia and New Zealand are also applying cost sharing 
measures for relocation or betterment works of utility works (Victoria State Government, 2004). It is not a difficult task to come up with such a standard or with such approach, but it needs collaboration, coordination and it is a teamwork. There is no standard approach in determining the cost but there are already many good practices and good methodology in place which has been practiced successfully.

Most of the respondents further added that site investigation process was done after the award of the road contracts and this gives rise to many fundamental and serious contractual disadvantages in terms of financial, project delivery and several other indirect cost to the economy as well to general public. Respondents (RE10 and R11) added as a measure to reduce the impact of utility relocation special clause in particular conditions of the condition of the road contract to be inserted clearly identifying the responsibility of the parties to the contract. Respondent (RE8) stated that allocating dedicated reserved corridor within Right of Way (ROW) right from inception during design stage will be of another way where such impacts can be eliminated. This may not be possible in a fully developed ROW in an area densely populated or in a commercial area where possibility of entire corridor would have been already utilised. In such circumstances, the road authority may grant conditional permission to obtain an undertaking letter confirming their unconditional acceptance to relocate their assets to desired location free of charge, when requested during road widening or any other infrastructure developments. Further, respondent (RE3) suggested to introduce an exclusive contract project works to mitigate time and cost implications and thereby entire project/contract sum of road project can be fully utilized for roads works without having to compromise for utility related works.

Moreover, respondent (RE3), added that land acquisition process to commence well ahead of commencement of road projects and offer attractive compensation package to landowners. Respondent (R8) suggested to simplify communications between the road and utility authorities and ensuring the prompt, timely and consistent provision of information and responses thereto by providing contact details and clarifying the roles and responsibilities of representatives assigned for various predetermined categories of work.

On the other hand, few respondents (RE1, RE3, RE6, RE8, and RE9), are of the view that each party must independently review information provided and advise the other party of any concerns in relation to cost impacts, timing, coordination, environmental and quality impacts. Defining efficient approval process for the construction, operation and maintenance of their respective assets as they relate to the delivery of each party's works programs ensuring high standards of safety, best practice construction methods, minimizing environmental impacts and ensuring value for money. Most of the respondents emphasized to acknowledge the need for ongoing communication and cohesive planning by sharing of information about their short and long-term project proposals and work programs to allocate and secure utility corridors within the Rights of Way. This should be done in a way that balances the road use and utility requirements and other community needs. Most of the respondents opined to avoid unnecessary re-digging of the same road, recognize the overall need for co-operation, efficiency, and effectiveness in the delivery of the works and the management of their respective assets to minimize potential project delays. Respondents (RE1 and RE8) stated that allocating dedicated reserved corridor within ROW right from inception during design stage will be of another way where such impacts can be eliminated. Respondent (RE3) stated that land acquisition process to commence well ahead of commencement of road projects and offer attractive compensation package to land owners.

\subsection{SUMMARY AND RESEARCH FINDINGS}

Table 2 below illustrates main issues and its impact experienced in Road projects as a result of utility works along with proposed mitigation measures.

\begin{tabular}{|c|c|c|}
\hline Current Issues & Impacts & Proposed Mitigation measures \\
\hline $\begin{array}{l}\text { - Lack of Coordination, } \\
\text { Communication between Road } \\
\text { \& Utility authorities } \\
\text { No MOU to share common } \\
\text { utility ROW corridor. } \\
\text { Absence of Cost sharing } \\
\text { agreement between Road \& } \\
\text { Utility authorities }\end{array}$ & $\begin{array}{ll}\text { - } & \text { Project Delay } \\
\text { - } & \text { Cost Implication } \\
\text { - } & \text { Time Implication } \\
\text { - } & \text { Public protect \& strike } \\
\text { - } & \text { Reduces life of new } \\
& \text { infrastructure by } 30 \% \text { \& is a huge } \\
\text { impact }\end{array}$ & 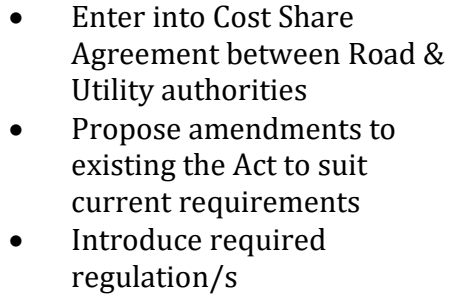 \\
\hline
\end{tabular}


- No corridor share arrangement and corridor reserve provision in ROW.

- $\quad$ Existing legal provisions not amended in keeping with current trend and practices

- $\quad$ Misconception \& mistrust

- Excessive delays in approvals

- $\quad$ Single corridor utilization though ample provision and opportunity available to accommodate to share
- Sharp increase in maintenance cost

- In the absence of agreed standard reserved utility corridors extensive damage caused to carriageways.

- Increase in abortive works

- Delays in execution of works

- Disruption to traffic and public inconvenience
- Introduce Code of practice Management of Infrastructure in Right of Way

- Establishment of a National Utility \& Road Co-ordination Entity (NURCE)

- Sign MOU between concerned entities

- Undertake land acquisition process prior to project award

- Develop common corridor concept and/or corridor share between utilities in ROW.

- Establish dedicated division /Department to deal with Utility Works in ROW

Table 2: Summary of Current issues, impacts and mitigation measures

\section{Conclusions and Recommendations}

At present there are no overall long-term agreements in place amongst roads authorities and utility owners that outline or facilitate to manage utility works during road project works within Sri Lanka. Moreover, this paper summarises wide ranging recommendations and several remedial measures to mitigate impacts of utility works. These measures are rarely considered in isolation but rather formulate part of the wider concept of utility works management. This includes promoting co-operation, co-ordination, and communication; the provision of utility corridors, avoiding unnecessary utility relocations and cost sharing agreement predominantly for utility relocation and betterment works. This is to achieve the common goal of providing the best value for money solution to the client with least disruption to the public

It is recommended to implement a development collaboration methodology to tackle better cooperation with road and utility authorities. Amongst other issues, they may be held accountable for any subsequent rise in project costs and delays when road authorities cancel or reduce the scope of a project due to utility, infrastructure issues, environmental problems, or right-of-way efforts. When implementing a road project, the executing entity should be advised to maintain close communication with stakeholders so as to prevent unnecessary delay caused by poor coordination. Additional recommendation and way forward include acknowledging the need for ongoing communication and cohesive planning by sharing of information about short- and long-term master plans/project proposals or work programs to allocate and secure utility corridors within the Right of Ways. This should be done in a way that balances the road use and utility requirements and other community needs. Avoid unnecessary re-digging of the same road, recognize the overall need for co-operation, efficiency, and effectiveness in the delivery of the works and the management of their respective assets to minimize potential project delays. Sound legislation will be defining the powers, rights and obligations of all transport and utility authorities and service providers. Overall MOU's need to be developed for 3-5 year period between the road authorities and utility service providers to promote co-operation, co-ordination, communication and effective dispute resolution methods. Necessary legislative provision for cost sharing of utility works in ROW shall be initiated by choosing methodologies most suitable for Sri Lanka. To identify and formulate cost sharing of utility relocation and the provision of new utility infrastructure between Roads Authority and the respective utility owners based on material type, age of utility, life span with option to benchmark good practices from developed countries.

\section{References}

Asphalt Industry Alliance, 2018. Annual Local Authority Road Maintenance Survey. [online] Available from: https://www.asphaltuk.org/wp-content/uploads/alarm-survey-2019-digital.pdf. (Accessed 18 September 2019).

Department of Transport (Abu Dhabi). Report on International Benchmarking Tour, 2013. (Accessed 4 September 2019) 
Department of Transport and Main Roads. [online] Available from: https://www.tmr.qld.gov.au/ (Accessed 17 July 2019)

Federal Highway Administration, 2014. Utilities Relocation and Accommodation (Office of International Programs, Chapter 5). [online] Available from: https://international.fhwa.RA.gov/eurorightofway/05.cfm. (Accessed 30 September 2019).

Government of the Victoria State, 2004. Vic Roads. [online] Available from: https://www.vicroads.vic.gov.au/ (Accessed 4 September 2019)

International Labour Organisation. 2019, Utilities (Water, Electricity, gas) Sector. [online]. Available from: https://www.ilo.org/global/industries-and-sectors/utilities-water-gas-electricity/lang--en/index.htm. (Accessed 9 October 2019).

Jayakanthan, J. and Jayawardane, A.K.W. 2012. Mitigating Delays in Donor Funded Road Projects in Sri Lanka. Engineer: Journal of the Institution of Engineers, Sri Lanka, [online] 45(1), p.65. Available from: https://engineer.sljol.info/articles/abstract/10.4038/engineer.v45i1.6950/ (Accessed 2 July 2019).

Hsieh, H. F., and Shannon, S. E., 2005. Three approaches to qualitative content analysis. Qualitative Health Research, 15(9), 1277-1288. doi.org/10.11/0973230526687

Ismail, J. M. 2021. Developing Strategies for Cost Sharing of Utilities in Sri Lankan Road Projects. Dissertation [online]. University of Moratuwa. Unpublished report. (Accessed 7 June, 2021)

New Zealand Ministry of Transport, 1989. Government Roading Powers Act 1989 substituted, on 1 August 2008, by section 50(1) of the Land Transport Management Amendment Act 2008 (2008 No 47). s.l.: Published under the authority of the New Zealand Government, 2011.

Perera, B.A.K.S., Indika, D., and Rameezdeen, 2009, Risk management in road construction: The case of Sri Lanka. [online]. Available from: https://doi.org/10.3846/1648-715X.2009.13.87-102. (Accessed 15 October 2019).

Pathiranage, Y.l., and Halwatura, R.U, 2010, Factors Influencing the Duration of Road Construction Projects in Sri Lanka Engineer - Journal of the Institution of Engineers, Sri Lanka Vol. XXXXIII (4). https://doi.org/10.4038/engineer.v43i4.6997.

Roachanakanan, K., 2003. A case study of cost overruns in a Thai condominium project. Doctoral dissertation, Texas A\&M University. Texas A\&M University. Available from: http://hdl.handle.net/1969.1/2298.

Teruo, K., 2005. Baseline Road Project (1) (11). [online] Available from: https://www.jica.go.jp/english/our_work/evaluation/oda_loan/post/2006/pdf/project24_full.pdf. (Accessed 30 October 2019).

Transportation Association of Canada - Association des transports du Canada, n.d. Management of Utilities in and Adjacent to the Public Right-of-Way: Survey of Current Practices. [online]. Available from: http://www.tacatc.ca/sites/tac-atc.ca/files/site/doc/resources/report-mgmt-utilities-row.pdf. (17 November 2019).

U.S Department of Transportation - Federal Highway Administration, n.d. [online]. Available from: http://international.fhwa.RA.gov/eurorightofway/05.cfm (last modified in November 7, 2014). (Accessed 19 June 2019).

Victoria State Govt., 2004. Road Management Act, regulations \& codes. [online]. Available from: https://www.vicroads.vic.gov.au/about-vicroads/acts-and-regulations/road-management-act-regulationsand-code. (Accessed 13 August 2019).

Wijekoon. S.B, and Attanayake, A.M.C.T.K., 2013. Study on the Cost Overruns in Road Construction Projects in Sri Lanka. [online] Available from: http://dl.lib.mrt.ac.lk/handle /123/8969. (Accessed 1 December 2019). 